\title{
Behavior of Two and Three Electrode Configuration and Different Mediators in Working Electrode on Development of Disposable Screen-Printing Biosensors for Determination of Free Cholesterol
}

\author{
Mónica Hernández-Cruz, ${ }^{1}$ Carlos Andrés Galán-Vidal, ${ }^{1 *}$ Giaan Arturo Álvarez-Romero, ${ }^{1}$ María Teresa \\ Ramírez-Silva, ${ }^{2}$ María Elena Páez-Hernández, ${ }^{1}$ and José Luis González-Vidal ${ }^{3 .}$ \\ 1 Universidad Autónoma del Estado de Hidalgo. Área Académica de Química. Carretera Pachuca Tulancingo Km 4.5, 42184 \\ Mineral de la Reforma, Hidalgo, México.galanv@uaeh.edu.mx. \\ 2 Universidad Autónoma Metropolitana-Iztapalapa. Departamento de Química, Área de Química Analítica. Av. San Rafael \\ Atlixco 186 Col. Vicentina. 09340 México, D. F., México. \\ 3 Universidad Autónoma del Estado de Hidalgo. Área Académica de Computación. Carretera Pachuca Tulancingo Km 4.5, \\ 42184 Mineral de la Reforma, Hidalgo, México.
}

Received August 1, 2011; accepted April 1, 2013

\begin{abstract}
In the present work the development of an amperometric transducer in order to build a free cholesterol biosensor in planar configuration is reported. The one single use disposable biosensors were constructed by screen printing process which is compatible with automated methodologies of production. Based in the incorporation of tetracyanoquinodimethane (TCNQ), Prussian blue (PB) or ferrite $\left(\mathrm{Fe}_{3} \mathrm{O}_{4}\right)$ as mediator or electrocatalytic agent, three types of electrochemical transducers were evaluated. The cholesterol biosensors require a sample volume of $7.2 \mu \mathrm{L}$, exhibits good reproducibility and selectivity and cover a lineal answer of 2-16 mM with detection limits from 0.3 to $1.6 \mathrm{mM}$. The characteristics of biosensors are satisfactory for the decentralized analysis of the lipid in blood since enclose the range of clinical interest (3.5-6.5 $\mathrm{mM})$.

Keywords: Cholesterol, mediator, transducer, amperometric biosensor, screen printing.
\end{abstract}

\section{Introduction}

Cholesterol is a substance of biomedical interest which the body can synthesize, but can also be obtained through diet. Besides being a precursor of bile acids and a component of cell membranes, cholesterol is also required in the biosynthesis of several important substances, many of which function as hormones. Though the importance of cholesterol, when it exceeds the normal level in blood can cause heart and kidney disease. In this sense, cholesterol is usually determined in blood and food [1]. A total cholesterol level in blood higher than $6.5 \mathrm{mM}$, implies an increased risk of suffering a heart attack [2]. Owing to the changes on our diet, it has increased the need to analyze this lipid in order to know our health status.

There are several methods of analysis for the determination of cholesterol; among of these techniques are reported spectrophotometry, chromatography and capillary electrophoresis [36]. However, many of the usual techniques up to date involves a prolonged time of analysis, large amounts of sample, trained personnel for the management of equipment and are expensive or are not applicable in decentralized way. In this sense, an electrochemical sensor is an alternative to overcome some of these shortcomings without sacrificing reliability over other instrumental methods of analysis.
Resumen. En el presente trabajo se reporta el desarrollo de un transductor amperométrico con la finalidad de construir un biosensor de colesterol en configuración plana. Basados en la incorporación de tetracianoquinodimetano (TCQN), azul de Prusia (AP) o ferrita $\left(\mathrm{Fe}_{3} \mathrm{O}_{4}\right)$ como mediador o agente electrocatalítico, fueron evaluados tres tipos de transductores electroquímicos. Los biosensores desechables de un solo uso fueron fabricados por serigrafía, la cual es compatible con metodologías automatizadas de producción. Los biosensores de colesterol requieren un volumen de muestra de $7.2 \mu \mathrm{L}$, exhiben buena reproducibilidad y selectividad y cubren una linealidad de 2-16 mM con un límite de detección de 0.3 a $1.6 \mathrm{mM}$. Las características de los biosensores son satisfactorias para el análisis descentralizado del lípido en sangre ya que cubren el intervalo de interés clínico (3.5-6.5 mM). Palabras clave: Colesterol, mediador, transductor, biosensor amperométrico, serigrafía.

Actually there are a broad variety of electrochemical biosensors for quantification of cholesterol [7]. However, only few of these biosensors embrace the concentration range required for analysis of blood serum (3.5-6.5 mM). Moreover, in most of the reports, construction methodology is not compatible with mass production processes to achieve reproducibility, low cost and miniaturization of the devices. In this sense, the reported developments are not viable for the analysis of cholesterol by the patient at home or by the doctor in his office in order to take timely action that will lead to improve health. Encouraged by these limitations, recently some studies have reported the development of planar electrochemical cholesterol biosensors produced by screen printing which are suitable for decentralized analysis [8-10].

Owing to the low cholesterol solubility in water and the low activity of enzymes commercially available, in order to increase the sensibility, the planar biosensors mentioned above usually involve expensive electrochemical transducers (platinum, gold, carbon nanotubes, etc.) compromising their commercial viability and cost. Currently there are only few developments available on the market whose performance may be improved [7]. Considering the shortcomings of the amperometric cholesterol biosensors mentioned above, it is important to improve the performance of these devices by means of increasing its 
sensitivity with low cost materials. Also it is relevant integrate the materials with productions process to obtain low cost biosensors. In this work we explore the development of a low cost electrochemical biosensor for the determination of free cholesterol based on a three electrodes configuration transducer incorporating different mediators.

\section{Experimental}

Materials and solutions. All solutions were prepared from commercially available A.C.S reagents. Cholesterol (Research Organics), $\mathrm{KCl}$ (Técnica Química, S.A), $\mathrm{KH}_{2} \mathrm{PO}_{4}$, $\mathrm{KHPO}_{4}, 7,7,8,8$-Tetracyanoquinodimethane TCNQ (Aldrich), $\mathrm{K}_{3}\left(\mathrm{FeCN}_{6}\right), \mathrm{K}_{4}(\mathrm{FeCN}), \mathrm{NaCl}, \mathrm{NaH}_{2} \mathrm{PO}_{4}, \mathrm{Na}_{2} \mathrm{HPO}_{4}$, acetonitrile, Triton X-100, Tween 80, glucose, acetaminophen, urea, creatinine, ascorbic acid and cholesterol oxidase from Pseudomonas flourescens $2.4 \mathrm{IU} / \mathrm{mg}$, carboxymethylcellulose (SigmaAldrich). All solutions were prepared with deionized water MilliQ (Millipore) $(18 \mathrm{M} \Omega \mathrm{cm})$. Cholesterol was dissolved with $2 \mathrm{~mL}$ of Tween 80 and $1 \mathrm{~mL}$ of Triton X-100 stirring until completely dissolved. Subsequently is diluted to $100 \mathrm{~mL}$ with a solution of $0.05 \mathrm{M}$ phosphate buffer $/ \mathrm{KCl} 0.1 \mathrm{M}$ at $\mathrm{pH} 7$ (PBS) forming a stable emulsion. The enzyme cocktail is prepared by dissolving cholesterol oxidase on carboxymethylcellulose (CMC) $0.25 \%$, previously dissolved in PBS.

Prussian blue (PB) was synthesized by mixing equal volumes of an aqueous solution of $\mathrm{FeCl}_{3} 2 \%$ and an aqueous solution of $\mathrm{K}_{4} \mathrm{Fe}(\mathrm{CN})_{6} 1 \%$. The Prussian blue precipitate (blue powder) was filtered and drying at $100{ }^{\circ} \mathrm{C}$ for $24 \mathrm{~h}$ [11]. Ferrite $\left(\mathrm{Fe}_{3} \mathrm{O}_{4}\right)$ was prepared by coprecipitation method, as follows: 0.03 mol $\mathrm{FeSO}_{4} .7 \mathrm{H}_{2} \mathrm{O}$ were dissolved in $100 \mathrm{~mL}$ of water. The mixture was stirred vigorously while the temperature was increased to $60^{\circ} \mathrm{C}$. A stream of air was bubbled in the mixture whilst a $\mathrm{NaOH}$ solution $(2 \mathrm{M})$ was added to adjust $\mathrm{pH}$ value to 10. After $1.0 \mathrm{~h}$, the ferrite precipitates were isolated from the solvent by a permanent magnet and washed several times with deionized water [12]. TCNQ-graphite material was prepared by mixing $1 \mathrm{~g}$. of graphite with $10 \mathrm{~mL}$ of TCNQ $0.1 \mathrm{M}$ in acetronitrile. The TCNQ-graphite was filtered and drying at $100{ }^{\circ} \mathrm{C}$ for $24 \mathrm{hrs}$.

Construction of transducers. Transducers were fabricated on a planar configuration of two and three electrodes. Both transducers were manufactured by screen printing with silkscreen manual equipment with screens of 90 lines by square inch and a standard polyurethane squeeze (Fig. 1). Commercial screen printing $\mathrm{Ag} / \mathrm{AgCl}$ paste Electrodag 7019 (Acheson) was used to print the reference electrode and graphite paste Electrodag PF-407C (Acheson) was used for both working and counter electrodes. Previous to the printing process of the working electrodes, the graphite paste was mixed with $5 \%$ of Prussian blue or 5\% TCNQ-graphite or $40 \%$ of ferrite. As encapsulant, it was used a photocurable dielectric paste 451SS (Acheson). Curing cycles were carried out at $40{ }^{\circ} \mathrm{C}$ for at least $30 \mathrm{~min}$ for thermosetting resins. The curing of photocurable encapsulant was completed for 1 hour under direct sunlight (Fig. 1).

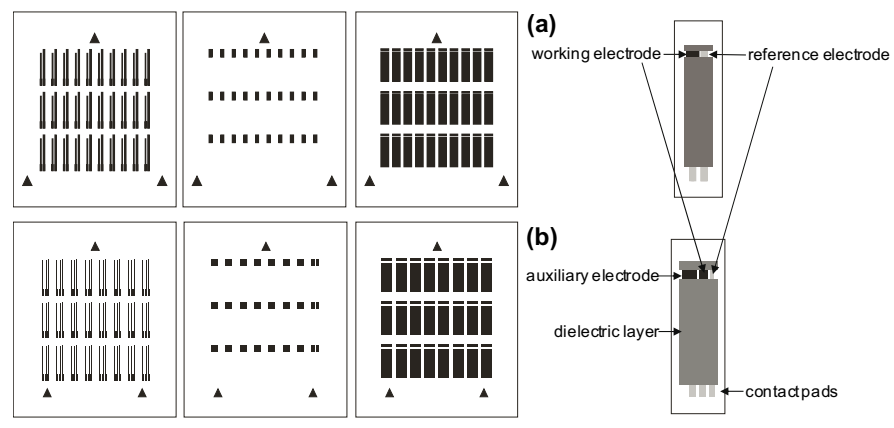

Fig. 1. Schematic drawing of the screen printed process for constructions of transducers. Left: tracks of $\mathrm{Ag} / \mathrm{AgCl}$ (reference electrode and contacts), graphite (working and counter electrode) and dielectric layer. a) batch of 30 electrode transducer strips in two electrodes configuration, b) batch of 21 electrode transducer strips in three electrodes configuration.

Construction of biosensors. Biosensors were constructed based only on electrochemical transducers with configuration of three electrodes for all type of transducers. Once built transducers, the enzyme was immobilized by placing $5 \mu \mathrm{L}$ of enzyme cocktail onto the surface of the electrode and dried in an oven incubator at $30^{\circ} \mathrm{C}$ for $30 \mathrm{~min}$. Once immobilized the enzyme, it is formed a channel with a capacity of $7.2 \mathrm{~mm}^{3}$ with a doublesided tape and an acetate sheet (Fig. 2).

Instrumentation. Cyclic voltammetry were obtained using PGSTAT 30 AUTOLAB electrochemical systems (Ecochemie). All chronoamperometric experiments were performed using a LC-4C amperometric detector (BAS). The electrochemical cell consisted on a planar graphite screen printed strip as working electrode (3X2 $\mathrm{mm}$ and $4 \mathrm{X} 2 \mathrm{~mm}$ for three and two electrodes configuration respectively), a planar graphite screen printed strip as counter electrode $(5 \mathrm{X} 2 \mathrm{~mm})$, and a planar $\mathrm{Ag} / \mathrm{AgCl}$ screen printed strip as reference electrode (1X2 mm and $2 \mathrm{X} 2$ $\mathrm{mm}$ for three and two electrodes configuration respectively), all integrated in one chip (Fig. 1). When necessary, a commercial $\mathrm{Ag} / \mathrm{AgCl}$ double junction electrode with $\mathrm{KNO}_{3} \quad 10 \%$ external solution $\mathrm{E}=\mathrm{SCE}$ (Orion 900200) and a commercial platinum auxiliary (MF-2013 BAS) were used. All the electrochemical studies were performed in PBS as supporting electrolite.

\section{Results and discussion}

\section{Amperometric transducers}

Given that the working electrode is printed on an $\mathrm{Ag} / \mathrm{AgCl}$ track, it is important to identify possible signs of oxidation or reduction which may affect the working electrode behavior. Hence, studies were carried out by means of cyclic voltammetry with the working electrode and silver/silver chloride contact pad (Fig. 3). In both cases both an external reference and a counter electrode was used.

The $\mathrm{Ag} / \mathrm{AgCl}$ pad shows three anodic signals. The first one $(280 \mathrm{mV})$ is attributable to the oxidation of $\mathrm{Ag}^{\circ}$ to $\mathrm{AgCl}$ because PBS contains $0.01 \mathrm{M}$ of chloride ions concentration. 
The second one shows the oxidation of $\mathrm{Ag}^{\circ}$ to $\mathrm{Ag}^{+}(570 \mathrm{mV})$, and the third one $(820 \mathrm{mV})$ probably is due to oxidation of some component of the screen printing paste, as vinyl monomers, stabilizers or additives.

According to the results obtained with graphite electrodes, we can observe how the track of $\mathrm{Ag} / \mathrm{AgCl}$ is in fact covered by the graphite during the construction process and no one signals of oxidation or reduction attributed to the $\mathrm{Ag} / \mathrm{AgCl}$ pad are present.

Amperometric biosensors operate under potentiostatic control mode. During its operation requires the imposition of an optimal potential established between the reference and working electrodes. Once satisfied this condition, the electrochemical processes which take place at the working electrode surface results in the flow of electric current across the cell which is proportional to the concentration of the analyte of interest.

According to the electrochemical system and the potential fixed, the working electrode can act as an anode or cathode. In order to maintain electroneutrality and not limit the current flow of the electrochemical cell, a complementary electrode must be used.

To carry out the measures with an amperometric transducer of two electrodes configuration, the reference electrode, in addition to helping the control of the potential imposition on the

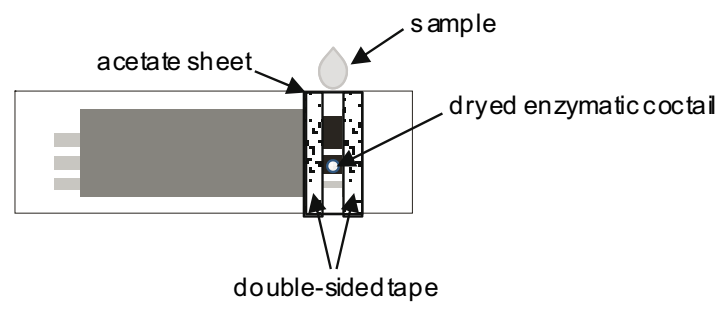

Fig. 2. Disposable cholesterol biosensor in a three electrode configuration. working electrode, enclose the function of counter electrode described above. This configuration represents cost advantages in the device and simplifying the construction process, but the current flow can cause changes in reference electrode potential because altering the activity of the chemical species that contain it. Since the current flow in the biosensor of cholesterol is commonly in the order of nanoamperes, this is not expected to be a significant change in the reference electrode potential.

In order to evaluate the electrochemical behavior of the two electrode transducers, cyclic voltammograms in ferrocynide were obtained using the reference electrode on the same chip (Fig. 4). The potential of this reference electrode is of $72 \pm 2 \mathrm{mV}$ vs SCE. The result shows two anodic and one cathodic peaks. The signals placed in $610 \mathrm{mV}$ and $-290 \mathrm{mV}$ are attributed to the average potential of oxidation/reduction of ferrocynide/ferricyanide system. The second anodic peak located at $880 \mathrm{mV}$ is attributed to the oxidation of a component of the reference paste $\mathrm{Ag} / \mathrm{AgCl}$ electrode. We suppose this compound migrates to the working electrode previous reduction on its surface.

In order to eliminate the problem of oxidation of the unexpected $\mathrm{Ag} / \mathrm{AgCl}$ paste component onto the working electrode, it was designed a transducer in a three electrode configuration where the auxiliary electrode is made of graphite.

Once constructed the three electrode transducer, it was evaluated by means of cyclic voltammetry in $\mathrm{Fe}(\mathrm{CN})_{6}{ }^{4-} 0.01 \mathrm{M}$ also. The voltammograms obtained shows the same oxidation/ reduction of ferrocynide/ferricyanide signals of the two electrode transducer, but without the $880 \mathrm{mV}$ peak, confirming that this signal is due to the use of the $\mathrm{Ag} / \mathrm{AgCl}$ as counter electrode in the two electrodes configuration transducer (Fig. 5.).

In order to evaluate the reproducibility of the transducer electrochemical signals, we obtained voltammograms of three transducers of the same batch. The devices show good reproducibility respect to the potential position and current peak (Table 1.).
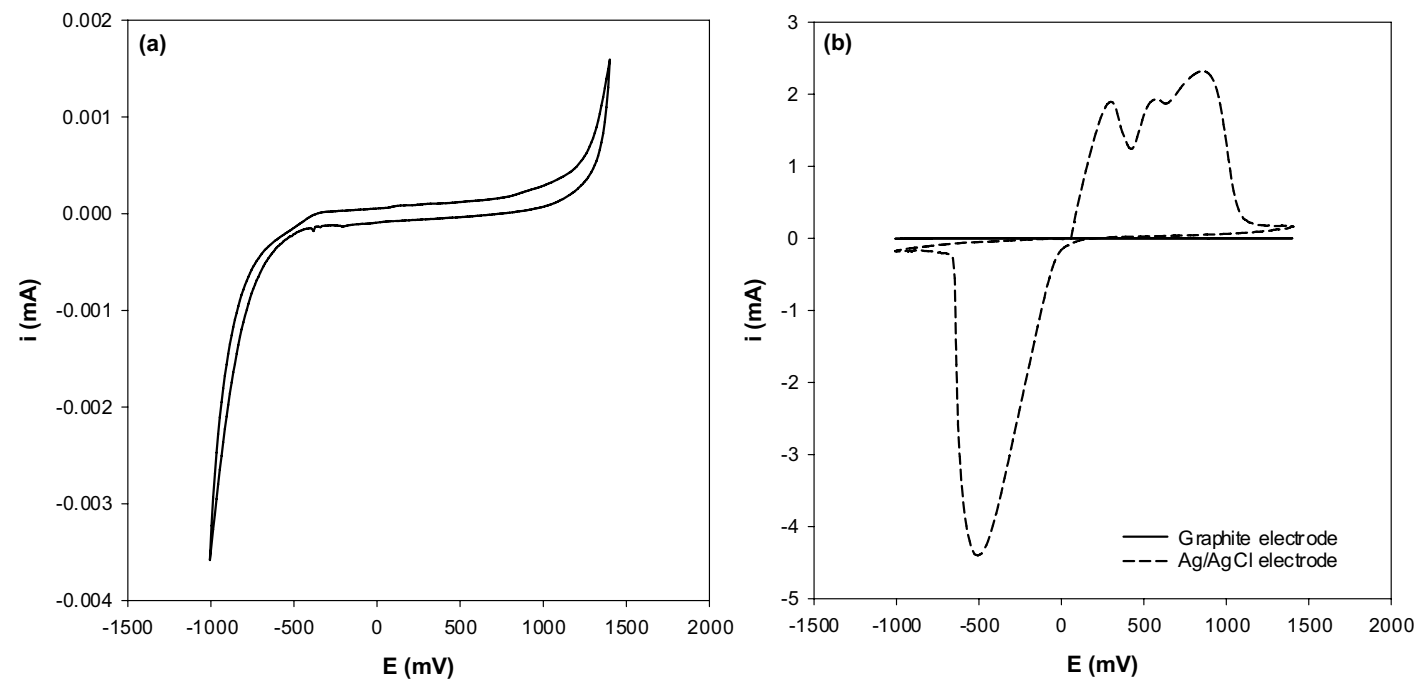

Fig. 3. Cyclic voltammograms of a screen printed graphite electrode of $8 \mathrm{~mm}^{2}$ (a) and a screen printed $\mathrm{Ag} / \mathrm{AgCl}$ contact pad of $4 \mathrm{~mm}^{2}$ (b) in PBS at $100 \mathrm{mV} / \mathrm{s}$. 


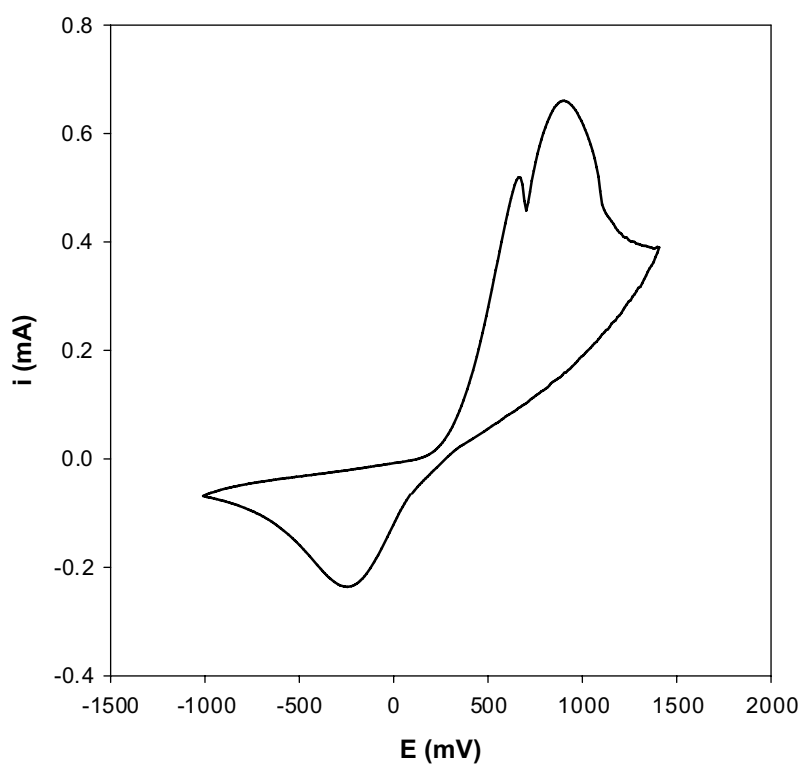

Fig. 4. Typical cyclic voltammogram of the of screen printing working electrode using $\mathrm{Ag} / \mathrm{AgCl}$ reference/auxiliary electrode on the same chip. $\mathrm{Fe}(\mathrm{CN})_{6}{ }^{4-} 0.01 \mathrm{M}$ in PBS, $100 \mathrm{mV} / \mathrm{s}$.

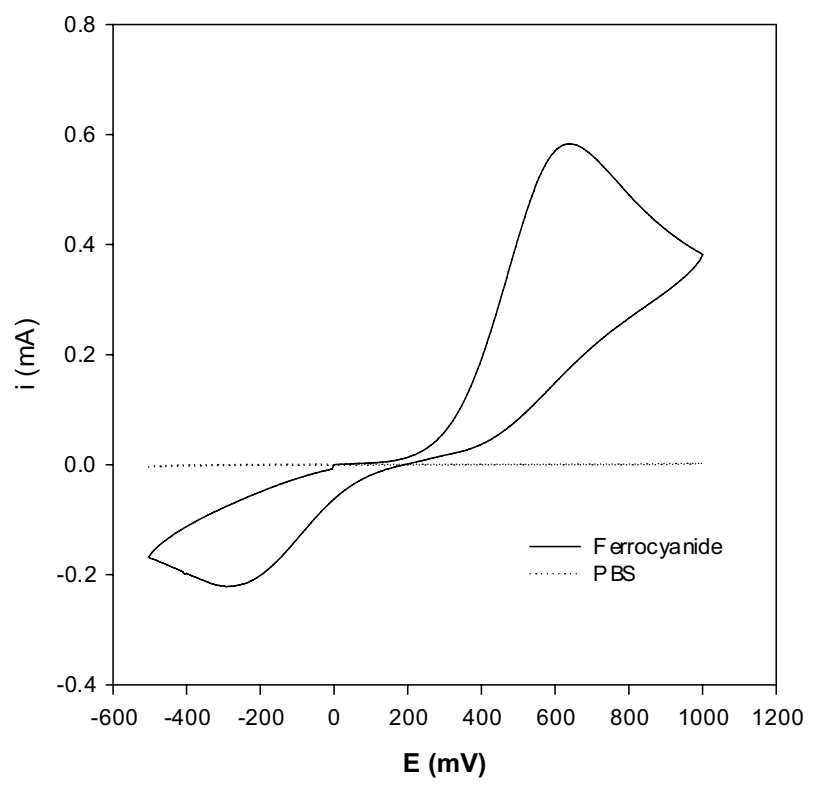

Fig. 5. Typical cyclic voltammogram of the of screen printing working electrode using both, a $\mathrm{Ag} / \mathrm{AgCl}$ reference and a graphite auxiliary electrodes on the same chip. $\mathrm{Fe}(\mathrm{CN})_{6}{ }^{4-} 0.01 \mathrm{M}$ in PBS, $100 \mathrm{mV} / \mathrm{s}$.

According to the results we can recognize how the electronic transference onto the transducer is not good because the broad difference between the oxidation and reduction peaks and the not ideal relation of current among anodic and cathodic peaks (Table 1). Nevertheless the transducers developed are useful because the small currents involved with cholesterol biosensors which are usually of nanoampers [13]. The three electrode transducer developed displayed a good behavior in the cronoamperometric studies obtained by means of succes-
Table 1. Signal reproducibility of screen printing 3 electrode transducers in $\mathrm{Fe}(\mathrm{CN})_{6}{ }^{4-} 0.01 \mathrm{M}$.

\begin{tabular}{lccccc}
\hline \multicolumn{1}{c}{ Transducer } & $\mathrm{Epa} / \mathrm{mV}$ & $\mathrm{ipa} / \mu \mathrm{A}$ & $\mathrm{Epc} / \mathrm{mV}$ & $\mathrm{ipc} / \mu \mathrm{A}$ & $\Delta \mathrm{E} / \mathrm{mV}$ \\
\hline $\mathrm{a}$ & 610 & 37 & -293 & -25 & 903 \\
$\mathrm{~b}$ & 605 & 34 & -298 & -24 & 903 \\
$\mathrm{c}$ & 615 & 36 & -283 & -22 & 898 \\
Standard & 4.9 & 1.4 & 7.5 & 1.1 & 2.8 \\
deviation SD & & & & & \\
Mean & 610.3 & 35.5 & -291.3 & -23.6 & 901.6 \\
\% relative SD & 0.8 & 3.8 & -2.6 & -4.8 & 0.3 \\
\hline
\end{tabular}

sive additions of ferrocyanide under magnetic stirred regime (Fig. 6). Respective calibration curve shows excellent linearity between 0.9 and $9 \mathrm{mM}$ of $\mathrm{Fe}(\mathrm{CN})_{6}{ }^{-4}$ with a regression coefficient of 0.99 .

Typical samples of blood contain a significant amount of ascorbic acid which is the principal interfering compound of amperometric biosensors [14, 15]. According to the cyclic voltammetry studies onto the three electrodes transducers, the current increase since $400 \mathrm{mV}$ (Fig. 7). In this sense, using the expected oxidation of hydrogen peroxide as analytical signal of biosensors of cholesterol is inadequate owing to it is oxidized at higher potentials c.a. $1150 \mathrm{mV}$ (Eq. 1).

Cholesterol $+\mathrm{O}_{2}+\mathrm{H}_{2} \mathrm{O} \stackrel{\text { ChOx }}{\longrightarrow}$ Cholest-4-en-3-one $+\mathrm{H}_{2} \mathrm{O}_{2}$

According to the interfering study and in order to obtain a useful transducer, it is necessary incorporate a mediator whose signal can be measured at potentials below $0.4 \mathrm{~V}$. This mediator must be easily integrated with mass production process of biosensors.

Prussian blue, ferrite and TCNQ were selected as mediators. Each one were incorporated at the working electrode paste according to the experimental section.

The interaction between cholesterol and the enzyme cholesterol oxidase generate hydrogen peroxidase and the enzyme has to be reactivated by oxygen (natural mediator) in order to preserve its activity (Eq. 1). The TCNQ works substituting the oxygen since $\mathrm{PB}$ and ferrite reduction is catalyzed by $\mathrm{H}_{2} \mathrm{O}_{2}$ (Eqs. 2-3).

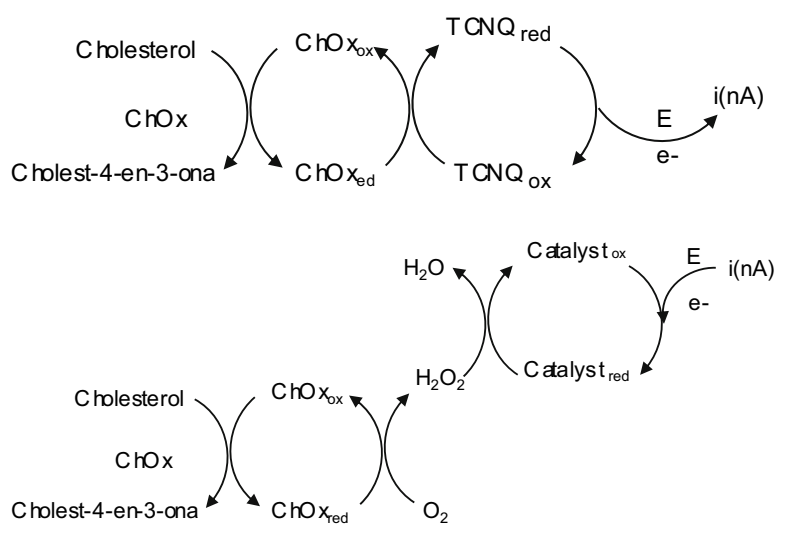



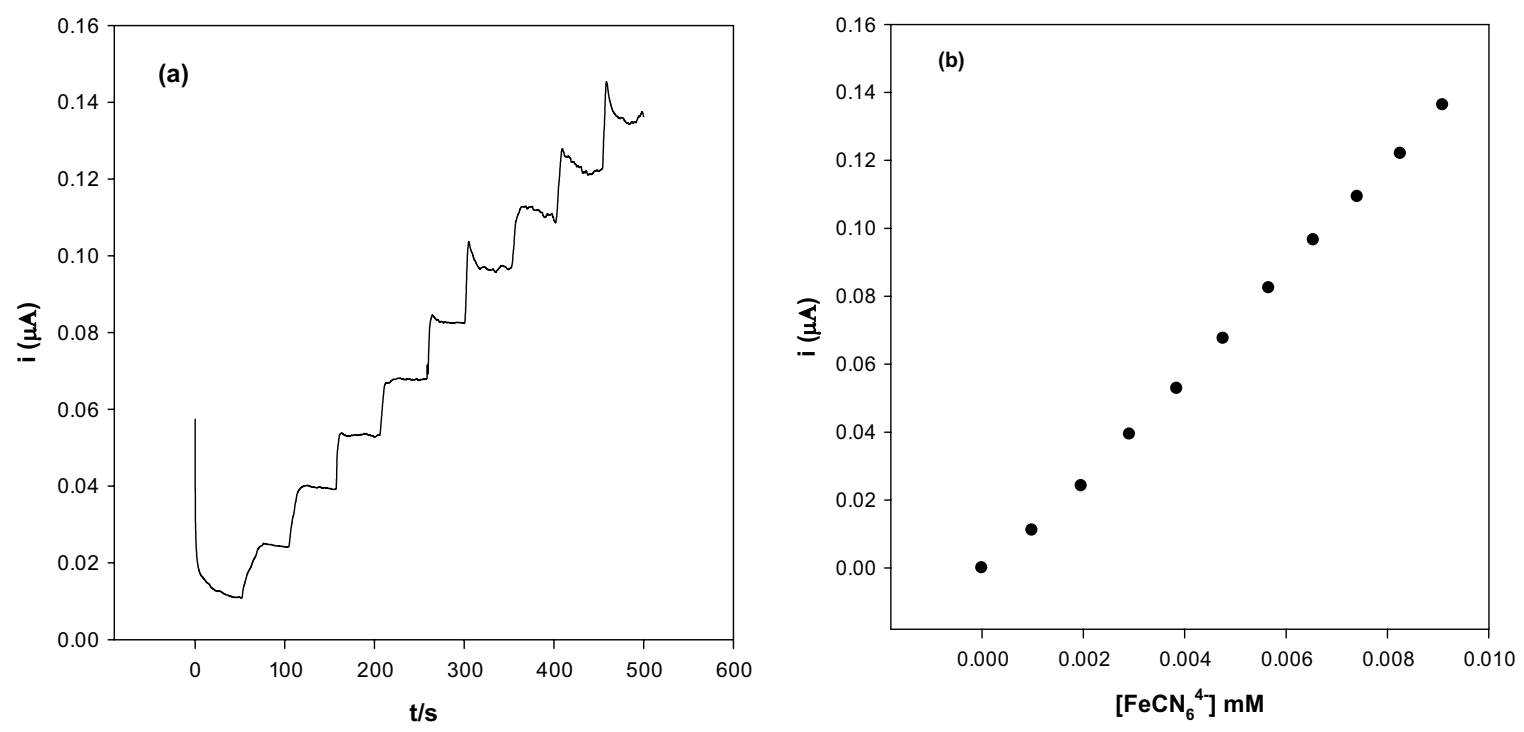

Fig. 6. (a) Dynamic response of the three electrode transducer for a ferrocyanide concentration range from 0 to $9 \mathrm{mM}$ in PBS. (b) Corresponding calibration graph. Applied potential: $0.6 \mathrm{~V}$.

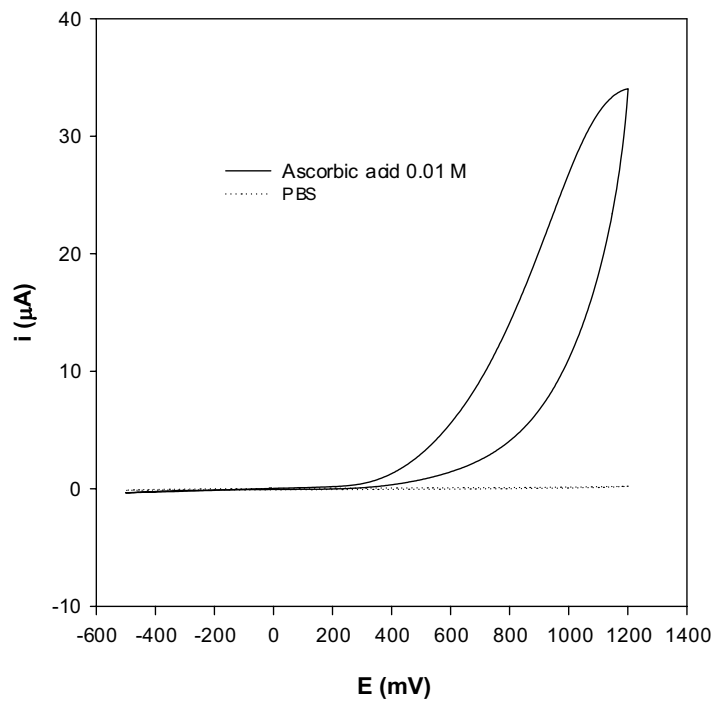

Fig. 7. Cyclic voltammogram of the of three electrode screen printed transducer in ascorbic acid $0.01 \mathrm{M}$ in PBS, $100 \mathrm{mV} / \mathrm{s}$.

The voltammograms of the three types of transducers are showed in Fig. 8. According to the results the selected working potentials were 150,0 and $-250 \mathrm{mV}$ for TCNQ, PB and ferrite respectively.

\section{Cholesterol biosensors}

Considering the three developed transducers, three different biosensensors were evaluated by means of chronoamperometric records (Fig. 9). In order to obtain the analytical parameters of the biosensors, calibration curves were performed for cholesterol from the chronoamperometric records at $100 \mathrm{sec}$. The results shows good proportionality of the current with respect to the concentration of cholesterol, having a linear behavior for concentrations in the range $2-16 \mathrm{mM}$ which include the blood normal levels of the lipid (3.5-6.5 mM). The detection limit calculated from the calibration curve according to the IUPAC recommendation is $1.56,1.29$ and $0.29 \mathrm{mM}$ for TCNQ, $\mathrm{PB}$ and ferrite respectively (Table 2 ).

The percentage of relative standard deviation (\%RSD) was $0.08-5.9 \%$ and $0.51-6.34 \%$, for TCNQ and ferrite cholesterol biosensors. Three readings were taken with three different biosensors for every measurement of the calibration curve, indicating good reproducibility of the devices. Reproducibility of PB cholesterol biosensors were not evaluated since its poor sensibility.

According to Michaelis-Menten enzyme kinetics model from the Lineweaver-Burk plot the apparent $\mathrm{Km}$ was obtained [16]. For each type of biosensor the calculated parameter is $0.32,0.66$ and $0.57 \mathrm{mM}$, being located reasonably close to the values reported for the enzyme in solution 0.11-0.25 $\mathrm{mM}$ [17], indicating that the activity of the enzyme was not strongly affected by the immobilization process.

Interference is always an important issue for the development of an electrochemical biosensor. The electrodes based on the use of cholesterol oxidase and measuring the release of hydrogen peroxide may be affected by the presence of interfering such as ascorbic acid, glucose, creatinine, etc., which are

Table 2. Analytical parameters of different type of screen printed cholesterol biosensors.

\begin{tabular}{lcccc}
\hline $\begin{array}{c}\text { Mediator or } \\
\text { electrocatalytic } \\
\text { agent }\end{array}$ & $\begin{array}{c}\text { sensitivity/(nA } \\
\left.\mathrm{mM}^{-1} \mathrm{~mm}^{-2}\right)\end{array}$ & $\begin{array}{c}\text { linearity/ } \\
\mathrm{mM}\end{array}$ & $\mathrm{DL} / \mathrm{mM}$ & $\mathrm{r}^{2} \geq$ \\
\hline TCNQ & 221 & $2-12$ & 1.6 & 0.99 \\
Prussian blue & 41 & $2-16$ & 1.3 & 0.98 \\
Ferrite & 132 & $2-10$ & 0.3 & 0.99 \\
\hline
\end{tabular}



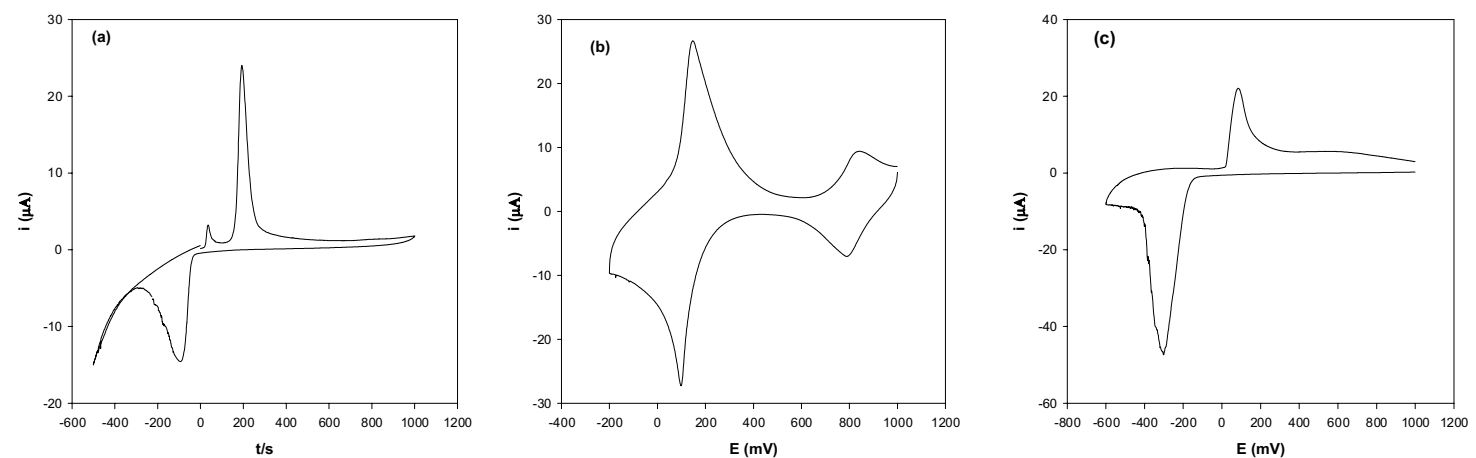

Fig. 8. Cyclic voltammograms of the three electrode transducers: (a) 5\% graphite-TCNQ, (b) $5 \%$ PB and (c) $40 \%$ ferrite, $(50 \mathrm{mV} / \mathrm{s})$.
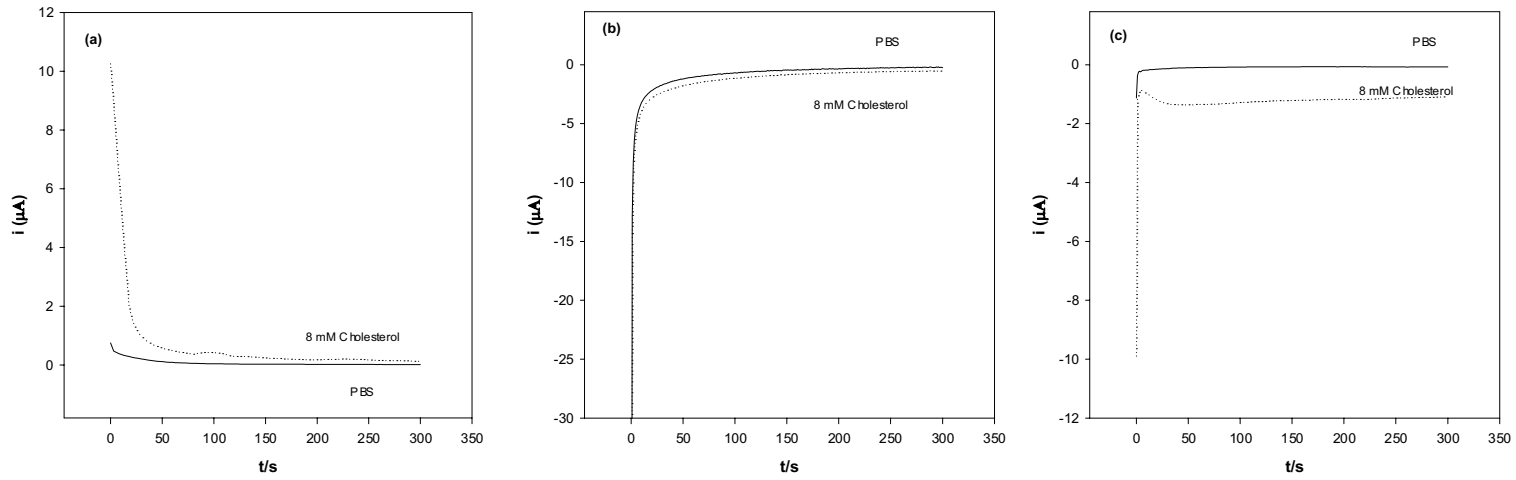

Fig. 9. Current records responses of three types of biosensors. (a) TCNQ E $=150 \mathrm{mV}$, (b) $\mathrm{PB} E=0 \mathrm{mV}$ and (c) ferrite $\mathrm{E}=-250 \mathrm{mV}$.

usually present in biological components such as blood samples or body fluids, therefore, the interference of these compounds has been studied for the ferrite cholesterol biosensor. These species were added into $2.5 \mathrm{mM}$ cholesterol standard solution in their normal physiological concentration (glucose $5.4 \mathrm{mM}$, urea $3.3 \mathrm{mM}$, creatinine $1.7 \mathrm{mM}$, ascorbic acid $1.1 \mathrm{mM}$ and paracetamol $1.3 \mathrm{mM}$ ). It has been found that the response of the biosensor for the electroactive species tested is negligible respect to the cholesterol standard measurement. This result is comparable to the TCNQ cholesterol biosensor for ascorbic acid (Table 3).

Making a comparison of our results with some screen printed biosensors in the literature it is revealed a really good sensitivity, indicating that the improvement in sensitivity is not necessarily related with use of expensive transducer materials, mediator or electrocatalytic agents (Table 4).

\section{Conclusions}

A low cost disposable free cholesterol biosensor has been developed based on a three electrodes transducer. The device has been fabricated by screen printing process and works efficiently in the clinical interest range. The selectivity and particularly high sensibility of the device is appropriate for decentralized use by means of commercial hand-held instrumentation without need of a skilled technician, as patients, nurses or doctors. This work demonstrates that it is not necessary the incorporation of precious metals or expensive chemicals in order to increase the selectivity and sensibility, which are some of the most important challenges of the clinical cholesterol analysis.

Table 3. Interference study for a ferrite cholesterol biosensor

\begin{tabular}{lcc}
\hline \multicolumn{1}{c}{ Test compound } & \% interference* & \%RDS $(\mathrm{n}=3)$ \\
\hline Glucose & -0.1 & 2.1 \\
Urea & -1.3 & 0.8 \\
Creatinine & -2.2 & 0.5 \\
Paracetamol & +2.6 & 2.3 \\
Ascorbic acid & $+0.4\left(3.6^{* *}\right)$ & 1.6 \\
\hline
\end{tabular}

The percentage of relative standard deviation (\%RSD) for the standard solution of cholesterol is 1.6. $* \%$ Interference $=\left[\left(I-I_{o}\right) / I_{o}\right] \times 100$. Where $\mathrm{I}$ is the response of the cholesterol + test compound and $\mathrm{I}_{\mathrm{o}}$ is the response of standard cholesterol solution. ${ }^{* *}$ For TCNQ cholesterol biosensor; in this case the $\% \mathrm{RSD}=1.8$ for the standard solution of cholesterol. 
Table 4. Characteristics of some screen printed cholesterol biosensors reported in literature based on cholesterol oxidase.

\begin{tabular}{llcc}
\hline \multicolumn{1}{c}{ Transducer material } & Mediator or electrocatalytic agent & sensitivity/(nA mM $\left.\mathrm{mm}^{-2}\right)$ & Ref. \\
\hline gold & mediatorless & 17 & {$[18]$} \\
graphite/nanotubes & ferrocyanide & 37 & {$[19]$} \\
graphite & ferrite & 87 & {$[20]$} \\
graphite/rhodium/gold/nanotubes & cytochrome P450 & 1120 & {$[8]$} \\
graphite & TCNQ & 221 & this work \\
graphite & ferrite & 132 & this work \\
graphite & Prussian blue & 41 & this work \\
\hline
\end{tabular}

\section{Acknowledgements}

This work was partially supported by Universidad Autónoma del Estado de Hidalgo and CONACyT (Ref: 62462). M.H.C is grateful for their studentship granted by CONACyT (203348).

\section{References}

1. Tudela, V. El colesterol: lo bueno y lo malo, Fondo de Cultura Económica, México, 2002

2. Henry, J. B.; Tood-Sanford, Diagnóstico y tratamiento clínico para el laboratorio, Salvat, México, 1990.

3. Ruiz-Gutiérrez, V.; Barron, L. J. R. J. Chromatog B. 1995, 671, 133-168.

4. Richmond, W. Ann. Clin. Biochem. 1992, 29, 577-597.

5. Hoving, E. B. J. Chromatog B. 1995, 671, 341-362.

6. Xiao-Hua X.; Ren-Kuan L.; Juan C.; Ping C.; Xiang-Yang L.; Ping-Fan R. J. Chromatog B. 2002, 768, 369-373.

7. Arya, S. K.; Datta, M.; Malhotra, B. D. Biosens Bioelectron. 2008, $23,1083-1100$
8. Carrara, S.; Shumyantseva, V. V.; Archakov, A. I.; Samorì, B. Biosens Bioelectron. 2008, 24, 148-150.

9. Domínguez, R.O.; Alonso-Lomillo M. A.; Arcos M. M. J. Talanta 2007, 73, 202-219.

10. Gilmartin, M. A. T.; Hart, J. P. Analyst 1994, 119, 2331-2336.

11. Karyakin A. A.; Karyakina E. E.; Gorton, L. Anal. Chem. 2000, $72,1720-1723$.

12. Rodriguez J. A.; Espinosa, J.; Aguilar-Arteaga, K.; Ibarra I. S.; Miranda, J. M. Microchim Acta. 2010, 171, 407-413.

13. Vikas,A.; Pundir C. S. Sensors \& Transducers. 2007, 83, 15041512

14. Wei-Chung, S.; Mei-Chun, Y.; Meng, S. L. Biosens. Bioelectron. 2009, 24, 1679-1678.

15. Fang, C.; He, J.; Chen, Z. Sens. Actuator B. 2011, 155, 545-550

16. Eggins, B. R. Chemical Sensors and Biosensors, John Wiley \& Sons, England, 2002

17. Vrielink, A.; Ghisla, S. FEBS Journal 2009, 276, 6826-6843

18. Shen, J.; Liu, C. C. Sens. Actuator B. 2007, 120, 417-425.

19. Li, G.; Liao, J. M. ; Hu, G. Q.; Ma, N. Z.; Wu, P.J. Biosens. Bioelectron. 2005, 20, 2140-2144.

20. Shih, W. C.; Yang, M. C.; Lin, M. S. Biosens. Bioelectron. 2009, 24, 1679-1678. 